\title{
Effect of Mycorrhizal Colonization on Nitrogen and Phosphorous Metabolism in Wheat (Triticum aestivum L.) under Water Deficit Stress
}

\author{
Babita Rani $^{1 *}$, Shashi Madan', K.D. Sharma ${ }^{2}$, Pooja ${ }^{2}$, \\ Mukesh Kumar Berwal ${ }^{1}$ and Ashwani Kumar ${ }^{3}$ \\ ${ }^{1}$ Department of Biochemistry, ${ }^{2}$ Department of Botany and Plant Physiology, \\ CCS HAU, Hisar - 125004, Haryana, India \\ ${ }^{3}$ Centre of Soil Salinity Research Institute, Karnal, Haryana, India \\ *Corresponding author
}

\section{A B S T R A C T}

\begin{tabular}{|l|}
\hline Ke y w o r d s \\
Mycorrhiza, Wheat, \\
$\begin{array}{l}\text { Water deficit, } \\
\text { Nitrogen metabolism, } \\
\text { Phosphorous } \\
\text { metabolism. }\end{array}$ \\
\hline Article Info \\
\hline $\begin{array}{l}\text { Accepted: } \\
10 \text { September } 2017 \\
\text { Available Online: } \\
10 \text { October } 2017\end{array}$ \\
\hline
\end{tabular}

To examine the effect of Arbuscular Mycorrhiza fungi (AMF) (Glomumos seae) on nitrogen and phosphorous metabolism in two wheat varieties at jointing and heading stage under water deficit stress conditions. NPK content was more in leaves and roots of AMF inoculated plants. Activities of Nitrate reductase (NR), Nitrite reductase (NiR) and Glutamine synthetase (GS) decreased in leaves and roots under stress conditions. The higher activities of NR, NiR and GS in mycorrhizal plants could also be attributed to the positive effect of inoculation on $\mathrm{N}$ acquisition and assimilation in plants. Higher phosphatase activity in WH 1025 than in WH 1105 might help the plants by maintaining higher $\mathrm{P}$ acquisition under stress conditions. Hence, overall results suggest that mycorrhizal symbiosis plays a vital role in enhancing the activities of nitrogen and phosphorous metabolizing enzymes and increased the nutrient content that enables the host plant to sustain the water stress conditions.

\section{Introduction}

Mycorrhiza is a symbiotic association between a group of soil fungi called arbuscular mycorrhizal fungi and plants. The successful association between plants and AMF constitutes a strategy to improve the nutritional status of both associates, which reduces the use of fertilizers specially phosphorus nutrition (Almagrabi and Abdelmoneim, 2012). The AMF take carbohydrates compounds from their plant host, while the plants benefit from the association by the increased nutrients uptake, which improve tolerance to abiotic stress (drought or salinity), as well as enhanced plant disease control (Auge, 2001; Song et al., 2011). The water stress is considered to be main factor the causing limitations to plant growth. The effects of drought on plant growth depend on several factors such as plant genetic resistance, stage of growth and duration of plant expose to drought. Drought is one of the major constraints on plant productivity worldwide and is expected to increase with climatic changes. Drought resistance in plants is strongly affected by their nutritional status. Soil-water deficit is tightly linked to low nutrient availability and to poor soil structure, so various hypotheses 
have been formulated to explain the underlying plant nutrition mechanisms involved in AM fungi induced resistance to drought. Arbuscular mycorrhizal fungi are widely beneficial fungi, symbiotically associated with higher plant roots. An increasing number of experiments have shown that AMF alters plant water relations and prevents drought stress (DS) under certain conditions (Gebauer and Meyer, 2003). An improved drought tolerance may result not only from direct water supply by extraradical mycorrhizal fungal hyphae, but also from indirect mycorrhizal effects, such as an improved nutrient status, hormonal regulation of stomata, a better osmotic adjustment in AMF plants and increased antioxidant levels in AMF plants.

It is well known that mycorrhizal association benefits host plants by increasing the nutrient acquisition area as the fungal hyphae extend beyond the root and into the nutrient undepleted zones. Also, the role of AMF is to overcome the nutrient limitation for plant growth by enhancing nutrient acquisition, especially phosphorus (P). Nevertheless, few authors have highlighted the importance of mycorrhizal association for nitrogen $(\mathrm{N})$ nutrition (Guescini et al., 2007; Roldan et al., 2008). Inorganic P has low solubility, which results in very low mobility; consequently, a depletion zone develops when roots absorb inorganic phosphate. The fungal hyphae reach to the depletion zone to absorb P. Further, the fungal hyphae also secrete enzymes that are capable of solubilizing unavailable forms of phosphate. Phosphatases catalyze the hydrolysis of phosphate esters and can be divided into two broad groups based on their pH optima: acid phosphatase and alkaline phosphatase. On the other hand, $\mathrm{N}$ is an important constituent of amino acids, proteins, nucleic acids, enzymes, vitamins, alkaloids and chlorophyll. The demand for $\mathrm{N}$ by plants is closely related to growth and cell differentiation. The key $\mathrm{N}$ metabolizing enzymes, viz. nitrate reductase (NR); catalyzes the reduction of nitrate $\left(\mathrm{NO}_{3}^{-}\right)$to nitrite $\left(\mathrm{NO}_{2}{ }^{-}\right)$, nitrite reductase $(\mathrm{NiR})$; catalyzes the further reduction of nitrite to ammonia $\left(\mathrm{NH}_{3}\right)$ and glutamine synthetase (GS), synthesizes glutamine from $\mathrm{NH}_{3}$. Mycorrhiza can also improve plant uptake of potassium (K). Potassium also plays a key role in plant water stress and has been found to be the cationic solute which is responsible for stomatal movement in response to drought stress, however the protection of mycorrhizal plants against water stress was related to the increase of $\mathrm{K}$ uptake by the mycorrhizal fungi (Roldan et al., 2008). Wheat is nature's unique gift to mankind as it is an excellent source of nutrition in terms of carbohydrates, minerals and proteins. Most of the wheat growing areas of the world experience environmental stresses such as water, salinity, chilling and high temperature etc. that adversely affect growth and yield (Semenov and Shewry, 2011). Infection with ectomycorrhizal fungi can increase the ability of plants to resist drought stress through morphophysiological and biochemical mechanisms. However, the metabolism of nitrogen and phosphorous metabolising enzyme activities in the ectomycorrhizal symbiosis remains poorly understood. Arbuscular mycorrhiza inoculation influences the physiological status by increasing root respiration and increased uptake of most of important nutrients. Wheat is an important food crop world over. Thus the present study was conducted to elucidate the role of nitrogen and phosphorous metabolizing enzymes in relation to drought stress tolerance in wheat crop.

\section{Materials and Methods}

\section{Plant materials and treatments}

The present investigation was carried out on two varieties of wheat viz. WH 1105 (Drought sensitive) and WH 1025 (Drought tolerant). 
Seeds were procured from Wheat and Barley Section, Department of Genetics and Plant Breeding, College of Agriculture, CCS HAU, Hisar. The experiment was laid out in CRD factorial design. Seeds were sterilized with alcohol, washed 3-4 times with distilled water and dried on. Plants of two varieties of wheat were raised in earthen pots $(20 \times 16 \mathrm{~cm})$ with $5 \mathrm{~kg}$ dune sand in natural conditions. In half number of pots seeds were inoculated with AMF and in another half pots, seeds were without AMF. Six seeds were sown in each pot at uniform depth. Thinning was done one week after germination to leave two plants of uniform growth in each pot. The plants were supplied with nutrient solution (Hoagland and Arnon, 1950) at regular intervals.

\section{Enzymes of nitrogen and phosphorous metabolism}

Nitrate reductase activity was determined Invivo conditions (Sawhney and Naik, 1972). The enzyme was assayed colorimetrically by monitoring the amount of nitrite produced. For determining in vivo activity of nitrate reductase, $250 \mathrm{mg}$ leaf discs were suspended in $10 \mathrm{ml}$ of a medium constituting $50 \mathrm{mM}$ phosphate buffer ( $\mathrm{pH} 7.5$ ), $20 \mathrm{mM} \mathrm{KNO}_{3}$ and $3 \% \quad(\mathrm{v} / \mathrm{v})$ n-propanol and then vacuum infiltrated till all the discs sank to the bottom of solution. These tubes were incubated in dark in an incubator at $30^{\circ} \mathrm{C}$. After 0,10 and $30 \mathrm{~min}, 1 / 10$ of aliquot was withdrawn and the amount of $\mathrm{NO}_{2}{ }^{-}$released was estimated by colorimetric method (Fewson and Nicholas, 1961). One unit of enzyme activity is defined as the amount of $1.0 \mu$ moles of $\mathrm{NO}_{2}{ }^{-}$formed $\mathrm{h}^{-1} \mathrm{~g}^{-1} \mathrm{f}$. wt. For determination of nitrite reductase activity two gram plant tissues were homogenized in $5 \mathrm{ml}$ cold $0.1 \mathrm{M}$ phosphate buffer ( $\mathrm{pH} 7.5$ ) containing $1 \mathrm{mM}$ cysteine, 20 $\mu \mathrm{M}$ FAD and $1 \%(\mathrm{w} / \mathrm{v})$ casein in a pre-chilled mortar using acid-washed sand as an abrasive. The homogenate was centrifuged at 10,000 $\mathrm{rpm}$ for $30 \mathrm{~min}$ at $4^{\circ} \mathrm{C}$ in a refrigerated centrifuge. The supernatant was carefully decanted and used for enzymes assays. Reaction mixture for assaying the enzyme activity, in the final volume of $2 \mathrm{ml}$, containing in $\mu$ moles: phosphate buffer $(\mathrm{pH}$ 7.5), 100; $\mathrm{NaNO}_{2}, 2.0 ;$ methyl viologen (MV), 0.4; and $0.1 \mathrm{ml}$ enzyme extract. The reaction was initiated by reducing $\mathrm{MV}$ with $0.1 \mathrm{ml}$ of freshly prepared sodium dithionite solution (prepared by dissolving $160 \mathrm{mg}$ each of Sodium dithionite and Sodium bicarbonate in $5 \mathrm{ml}$ of distilled water). After incubation at $30^{\circ} \mathrm{C}$ for $30 \mathrm{~min}$, the reaction was stopped by vigorously shaking the tubes till the blue colour of reduced methyl viologen completely disappeared. The blank tubes containing either boiled enzyme extract or in this methyl viologen was completely oxidized before addition of enzyme. The aliquot $(0.1 \mathrm{ml})$ was withdrawn from each tube and the residual $\mathrm{NO}_{2}{ }^{-}$was estimated by the colorimetric method (Fewson and Nicholas, 1961). One unit of enzyme activity is defined as the amount of $1.0 \mu$ moles of $\mathrm{NO}_{2}^{-}$used $h^{-1} \mathrm{~g}^{-1} \mathrm{f}$. wt.

\section{Assay of glutamine synthetase activity}

Two gram of plant leaf tissue was homogenized in $5 \mathrm{ml}$ of cold $0.1 \mathrm{M}$ phosphate buffer ( $\mathrm{pH}$ 7.6) containing $2 \%$ polyvinyl pyrrolidone (PVP), $1 \% \quad \beta$-mercaptoethanol and $10 \mathrm{mM}$ dithiothreitol (DTT) in previously chilled pestle-mortar using acid-washed sand as an abrasive (Boland et al., 1978). The homogenate was centrifuged at $10,000 \times \mathrm{g}$ for $30 \mathrm{~min}$ at $4^{\circ} \mathrm{C}$ in a refrigerated centrifuge (Remi, CPR-24). The supernatant was carefully decanted and used for enzymes assays.

The activity of glutamine synthetase (transferase activity) was assayed colorimetrically by estimation the amount of $\gamma$ glutamyl monohydroxamate ( $\gamma \quad-\mathrm{GMH})$ produced (Kanamori and Matsumoto, 1972). 
Reaction mixture for assaying the enzyme activity, in the final volume of $2 \mathrm{ml}$, containing in $\mu$ moles: Tris-HCl buffer ( $\mathrm{pH} 7.2), 150$; glutamine, 150; hydroxylamine hydrochloride (neutralized), 70; ADP, 1.2; sodium arsenate, $80 ; \mathrm{MnCl}_{2}, 1.5$ and $0.1 \mathrm{ml}$ enzyme extract.

Hydroxylamine hydrochloride was omitted from the blank. The tubes were incubated at $27^{\circ} \mathrm{C}$ for 30 minutes and then the reaction was stopped by adding $2 \mathrm{ml}$ of stop mixture containing $4 \mathrm{ml}$ of $10 \% \mathrm{FeCl}_{3}, 1 \mathrm{ml}$ of $24 \%$ TCA, $0.5 \mathrm{ml}$ of $6 \mathrm{~N} \mathrm{HCl}$ and $6.5 \mathrm{ml}$ of distilled water.

\section{Assay of Acid and Alkaline phosphatase activity}

Two gram of leaf and root tissues were homogenized in $5 \mathrm{ml}$ of extraction buffer containing $0.4 \mathrm{M}$ Sucrose, 0.1 M KCL, 10 $\mathrm{mM} \mathrm{MgCl} 2,0.01 \mathrm{M}$ EDTA (Ethylene diamine tera acetic acid), $0.01 \mathrm{M}$ Mercepto ethanol, 2.5\% PVP (Polyvinyl pyrolidone) in a chilled glass mortar with a pestle using glass beads as abrasive. The homogenate so obtained was centrifuged at $10,000 \mathrm{rpm}$ for $20 \mathrm{~min}$ in a refrigerated centrifuge at $4^{\circ} \mathrm{C}$. The supernatant was used for estimating the activities of alkaline and acid phosphatase.

Alkaline and acid phosphatase was assayed by colorimetric method (Jones, 1998). The reaction mixture for alkaline phosphatase consisting of $250 \mu \mathrm{l}$ of enzyme extract and $250 \mu \mathrm{l}$ of substrate solution $(0.1 \mathrm{M}$ tris $\mathrm{HCl}$ buffer ( $\mathrm{pH}$ 7.8), 2mM P - nitrophenyl phosphate, $0.1 \mathrm{M} \mathrm{MgCl}_{2}$ was incubated at $37^{\circ} \mathrm{C}$ for 20 minute and the reaction mixture for acid phosphatase consisting of $250 \mu \mathrm{l}$ of enzyme extract and $250 \mu \mathrm{l}$ of substrate solution (0.1 M acetate buffer ( $\mathrm{pH} 4.8), 2 \mathrm{mM} \mathrm{P}$ nitrophenyl phosphate, $0.1 \mathrm{M} \mathrm{MgCl}_{2}$ was incubated at $37^{\circ} \mathrm{C}$ for 20 minute. Reaction was stopped with $5 \mathrm{ml}$ of $0.1 \mathrm{~N} \mathrm{NaOH}$ and the pnitrophenol liberated was determined by measuring colour intensity at $410 \mathrm{~nm}$. A standard curve was also prepared by using pure p-nitrophenol. The enzyme activity was expressed one unit equal to $1.0 \mu$ mole of $p$ nitrophenyl phosphate converted to $\mathrm{p}$ nitrophenol $h^{-1} g^{-1}$ f. wt.

\section{Estimation of $N, P, K$ content}

Total $\mathrm{N}$ in soil and plant samples was determined by micro-Kjeldahl method (AOAC, 2000), Total $\mathrm{P}$ in Soil and plant samples is determined by photometric method (Jackson, 1973) and Total potassium was estimated by flame photometer method (Koenig and Johnson, 1942). Soil moisture content was estimated by Gravimetric method.

\section{Statistical analysis}

All the data were subjected to variance analysis using the SAS (Version 9.3, SAS Institute Inc., Cary, NC, USA) and the significance was tested at 5\% level of critical difference.

\section{Results and Discussion}

The studies on symbiotic relationship between arbuscular mycorrhizal fungi (AMF) and the roots of higher plants have demonstrated that AMF symbiosis is a key component in helping plants to cope with water stress and in increasing drought resistance (Ruiz-Lozano, 2003; Smith and Read, 2008; Ruiz-Lozano and Aroca, 2010). Soil moisture observed was $15.6 \%$ in irrigated soil and 6.7 and $5.8 \%$ at jointing and heading stage respectively under drought conditions. In the present study, activities of NR, NiR and GS activities decreased under stress conditions in leaves and roots of both the varieties at both the growth stages. In mycorrhizal inoculated plants activities of these enzymes were reported higher over uninoculated control plants at jointing and heading stage of both the varieties (Figures 1, 2 and 3). 


\section{Enzymes of Nitrogen metabolism}

\section{Nitrate reductase (NR), Nitrite reductase (NiR) activity}

The response of nitrate reductase (NR), nitrite reductase (NiR) and Glutamine synthetase (GS) activity in leaves and roots of WH 1025 and WH 1105 under drought stress presented in Figures 1, 2 and 3 revealed that activity of all three enzymes in both leaves and roots was significantly affected by stress and mycorrhizal treatment. Drought stress decreased the activity of all three enzymes in leaves and roots of AMF inoculated and uninoculated plants. The AMF colonization in leaves of WH 1025 increased the NR activity by 33.7 and $38.9 \%$ at jointing and 38.6 and $43.7 \%$ at heading stage under control and stress conditions respectively.

However in WH 1105 variety, NR activity was lower than WH 1025 under stress conditions. Similar results were found in roots of both the varieties. The AMF inoculation in WH 1025 increased the activity by $33.6 \%$ at jointing and $43.8 \%$ at heading stage under stressed conditions. In case of WH 1105 AMF inoculated plants, activity of NR decreased by 49.4 and $54.7 \%$ at jointing and heading stage respectively under water limiting conditions (Figure 1).

In WH 1025 AMF treatment increased the nitrite reductase (NIR) activity by $8.7,14.0 \%$ and $10.0,27.8 \%$ in $\mathrm{WH} 1105$ at jointing and heading stage respectively under water deficit conditions. Similar results were observed in roots of both the varieties. In WH 1025 AMF treatment increased the activity by 29.8 and $32.3 \%$ at jointing and heading stage respectively under stress conditions as compared to AMF uninoculated plants (Figure 2). Similar pattern was found in $\mathrm{WH}$ 1105 but lower activity was observed than WH 1025 under control and stress conditions.

\section{Glutamine synthetase activity}

The GS activity was found more in leaves and roots of WH 1025 than in WH 1105 under stress and AMF treatment. In AMF inoculated leaves, maximum GS activity was 295.4 units $\mathrm{g}^{-1}$ f. wt. in WH 1025 and 214.9 was units $\mathrm{g}^{-1}$ f. wt. in WH 1105, at heading stage under water stress conditions (Figure 3). Similar trend was observed in roots of both the varieties under stress and AMF treatment. In roots, GS activity was found less than leaves in both the varieties. In AMF inoculated roots of WH 1025, GS activity increased by $14.7 \%$ at jointing and $20.3 \%$ at heading stage over the AMF uninoculated plants under water stress conditions. Similar pattern was found in WH 1105.

Similarly inoculation of AMF increased NR, $\mathrm{NiR}$ and GS activities in Dendrobium chrysanthum (Hajong, et al., 2013), NR activity in mycorrhizal plants of Wedilla chinensis (Osbeck) Merril (Nisha and Kumar, 2010). Enhanced NiR activity was reported in ectomycorrhizal inoculated plants of Tilia platyphyllos Scop (Guescini et al., 2007). Glutamine synthetase activity in AMF inoculated plants increased under drought conditions, which may be attributed to the hyphal transport of $\mathrm{N}$ in the form of $\mathrm{NO}_{3}{ }^{-}$or $\mathrm{NH}_{4}{ }^{+}$(Tobar et al., 1994).

When poplar leaves were submitted to water stress, GS activity decreased (Sibout and Guerrier 1998). It may be due to decreased ability of plants to reduce and assimilate nitrogen through the inhibition of enzymes implicated in nitrogen metabolism, such as NR and GS. Nitrate reductase, the first enzyme in the pathway of nitrate assimilation, has proved to be one of the enzyme that exhibits declining activity in water-stressed leaves of several species, including barley (Fresneau et al., 2007). Drought-related depletion of essential nutrients, particularly 
nitrate, can also cause changes in gene expression and enzyme activity. The higher activities of NR, NiR and GS in mycorrhizal plants could also be attributed to the positive effect of inoculation with mycorrhizal fungi on $\mathrm{N}$ acquisition and assimilation in plants (Azcon et al., 2001).

The higher activity of GS relative to NR and $\mathrm{NiR}$ activity in both, mycorrhizal inoculated and uninoculated plants, might be due to assimilation of $\mathrm{NH}_{4}{ }^{+}$ions derived from the primary $\mathrm{NO}_{3}{ }^{-}$reduction as well as other metabolic pathways, including direct uptake, photorespiration and amino acid catabolism (Ireland and Lea, 1999). The higher activities of NR, NiR and GS in WH 1025 than in WH 1105 in both AMF inoculated and uninoculated plants may be due to improved growth of this variety under water stress through maintaining a constant protein and nitrogen content.

\section{Enzymes of phosphorous metabolism}

\section{Acid and alkaline phosphatase activity}

The activities of acid and alkaline phosphatases were higher in AMF inoculated and non-inoculated plants of both varieties under stress conditions. The effect of AMF and drought stress on acid and alkaline phosphatase activity is shown in Figures 4 and 5. Activity of both the enzymes increased in mycorrhizal inoculated and uninoculated leaves and roots of both varieties under water stress. In AMF inoculated leaves of WH 1025 , phosphatase activity increased from 24.8 units $\mathrm{g}^{-1} \mathrm{f}$. wt. at jointing stage to 35.5 units $\mathrm{g}^{-1} \mathrm{f}$. wt. at heading stage under stress conditions (Figure 4).

Similar trend was observed in roots of both the varieties. In roots of WH 1025 mycorrhozal inoculation increased activity by $28.1,34.7 \%$ and $19.5,30.9 \%$ in WH 1105 at jointing and heading stage respectively under stress conditions. Alkaline phosphatase activity was found higher at heading stage than at jointing stage of both the varieties. In mycorrhizal leaves of WH 1025, activity increased by 1.7 fold and 1.8 fold in $\mathrm{WH}$ 1105 from jointing to heading stage under stress conditions. In roots also, higher activity was observed in WH 1025 than WH 1105 under water stress conditions irrespective of AMF treatment (Figure 5). In roots of AMF inoculated plants, activity was found 33.4 and $31.1 \%$ in WH 1025 however, 26.3 and $31.5 \%$ in $\mathrm{WH} 1105$ as compared to AMF uninoculated plants at jointing and heading stage respectively under water stress conditions. The results are in consistent with those studied that inoculation of $G$. intraradices and Sinorhizobium meliloti resulted in enhanced availability of phosphorous which could be due to release of more $\mathrm{P}$ with the increase of soil acid phosphatase mediated by AMF inoculation and might thus partially alleviate plant drought stress. The positive effect of mycorrhizal association on the activity of acid and alkaline phosphatases was also observed in Dendrobium chrysanthum (Stancheva et al., 2008). The application of AMF to seedlings of Catharanthus roseus (L) resulted in higher activities of acid and alkaline phosphatase as compared to uninoculated controls (Hajong et al., 2013).

In present study the estimated higher acid phosphatase activity than alkaline phosphatase was observed might be because of plant alkaline phosphatases generally display substrate specificity, and play defined roles in metabolism, whereas, acid phosphatases are generally nonspecific with the exception of PEP phosphatase (Ratti et al., 2010). Higher phosphatase activity in WH 1025 than in WH 1105 might help the plants in drought tolerance by maintaining higher $\mathrm{P}$ acquisition under stress conditions. 
Table.1 Nitrogen, Phosphorous, Potassium content in soil before sowing and after harvesting

\begin{tabular}{|c|c|c|c|}
\hline Soil nutrients & $\mathbf{N}$ (Kg/ha) & $\mathbf{P}$ (Kg/ha) & K (Kg/ha) \\
\hline Before sowing & 224 & 28 & 320 \\
\hline After harvesting & 203 & 21 & 290 \\
\hline
\end{tabular}

Table.2 Effect of Arbuscular mycorrhizal fungi on nitrogen content in wheat plants under control and drought stress condition at different growth stages

\begin{tabular}{|c|c|c|c|c|c|c|c|c|c|c|c|c|c|c|c|c|}
\hline Part of plant & \multicolumn{8}{|c|}{ Leaves } & \multicolumn{8}{|c|}{ Roots } \\
\hline Varieties & \multicolumn{4}{|c|}{ WH -1025} & \multicolumn{4}{|c|}{ WH - 1105} & \multicolumn{4}{|c|}{ WH -1025} & \multicolumn{4}{|c|}{ WH - 1105} \\
\hline Stage & \multicolumn{2}{|c|}{ Jointing } & \multicolumn{2}{|c|}{ Heading } & \multicolumn{2}{|c|}{ Jointing } & \multicolumn{2}{|c|}{ Heading } & \multicolumn{2}{|c|}{ Jointing } & \multicolumn{2}{|c|}{ Heading } & \multicolumn{2}{|c|}{ Jointing } & \multicolumn{2}{|c|}{ Heading } \\
\hline Treatments & $\mathbf{C}$ & $\mathbf{S}$ & $\mathbf{C}$ & $\mathbf{S}$ & $\mathbf{C}$ & $\mathbf{S}$ & $\mathbf{C}$ & $\mathbf{S}$ & $\mathbf{C}$ & $\mathbf{S}$ & $\mathbf{C}$ & $\mathbf{S}$ & $\mathbf{C}$ & $\mathbf{S}$ & $\mathbf{C}$ & $\mathbf{S}$ \\
\hline $\begin{array}{c}\text { Non AMF } \\
\text { (uninoculated) }\end{array}$ & 1.72 & 1.64 & 1.92 & 1.82 & 1.75 & 1.69 & 2.08 & 1.87 & 1.48 & 1.41 & 1.51 & 1.44 & 1.49 & 1.41 & 1.53 & 1.43 \\
\hline AMF & 1.81 & 1.71 & 2.07 & 1.94 & 1.93 & 1.79 & 2.18 & 2.10 & 1.78 & 1.74 & 1.85 & 1.78 & 1.82 & 1.75 & 1.98 & 1.89 \\
\hline CD@5\% & $\begin{array}{l}\mathrm{A}(\mathrm{Al} \\
\mathrm{B}(\mathrm{Str} \\
\mathrm{A} \times \mathrm{B}\end{array}$ & $\begin{array}{l}\text { treat } \\
\text { s treat } \\
\text { nterac }\end{array}$ & $\begin{array}{l}\text { ent) }-( \\
\text { ent })- \\
n)-0\end{array}$ & $\begin{array}{l}396 \\
396 \\
60\end{array}$ & $\begin{array}{l}\mathrm{A}(\mathrm{AN} \\
\mathrm{B}(\mathrm{Str} \\
\mathrm{A} \times \mathrm{B}\end{array}$ & $\begin{array}{l}\text { treatr } \\
\text { ntereat }\end{array}$ & $\begin{array}{l}\text { ent) }-( \\
\text { ent })- \\
\text { n) }-0\end{array}$ & $\begin{array}{l}590 \\
590 \\
35\end{array}$ & $\begin{array}{l}\text { A (AN } \\
\text { B (Str } \\
\text { A X B }\end{array}$ & $\begin{array}{l}\text { treatr } \\
\text { s treat } \\
\text { nteract }\end{array}$ & $\begin{array}{l}\text { nt) }-( \\
\text { nt) }- \\
\text { n) }-N\end{array}$ & $\begin{array}{l}78 \\
378 \\
.\end{array}$ & $\begin{array}{l}\mathrm{A}(\mathrm{Al} \\
\mathrm{B}(\mathrm{St} 1 \\
\mathrm{A} \times \mathrm{B}\end{array}$ & $\begin{array}{l}\text { treatr } \\
\text { s treat } \\
\text { nterac }\end{array}$ & $\begin{array}{l}\text { nt) }-1 \\
\text { nt) }- \\
\text { n) }-1\end{array}$ & $\begin{array}{l}10 \\
010 \\
29\end{array}$ \\
\hline
\end{tabular}

Table.3 Effect of Arbuscular mycorrhizal fungi on phosphorous content in wheat plants under control and drought stress condition at different growth stages

\begin{tabular}{|c|c|c|c|c|c|c|c|c|c|c|c|c|c|c|c|c|}
\hline Part of plant & \multicolumn{8}{|c|}{ Leaves } & \multicolumn{8}{|c|}{ Roots } \\
\hline Varieties & \multicolumn{4}{|c|}{ WH -1025} & \multicolumn{4}{|c|}{ WH -1105} & \multicolumn{4}{|c|}{ WH -1025} & \multicolumn{4}{|c|}{ WH -1105} \\
\hline Stage & \multicolumn{2}{|c|}{ Jointing } & \multicolumn{2}{|c|}{ Heading } & \multicolumn{2}{|c|}{ Jointing } & \multicolumn{2}{|c|}{ Heading } & \multicolumn{2}{|c|}{ Jointing } & \multicolumn{2}{|c|}{ Heading } & \multicolumn{2}{|c|}{ Jointing } & \multicolumn{2}{|c|}{ Heading } \\
\hline Treatments & $\mathbf{C}$ & $\mathbf{S}$ & $\mathbf{C}$ & $\mathbf{S}$ & $\mathbf{C}$ & $\mathbf{S}$ & $\mathbf{C}$ & $\mathbf{S}$ & $\mathbf{C}$ & $\mathbf{S}$ & $\mathbf{C}$ & $\mathbf{S}$ & $\mathbf{C}$ & $\mathbf{S}$ & $\mathbf{C}$ & $\mathbf{S}$ \\
\hline $\begin{array}{c}\text { Non AMF } \\
\text { (uninoculated) }\end{array}$ & 0.323 & 0.283 & 0.357 & 0.313 & 0.343 & 0.293 & 0.373 & 0.333 & 0.220 & 0.200 & 0.237 & 0.217 & 0.217 & 0.197 & 0.240 & 0.213 \\
\hline $\mathrm{AMF}$ & 0.373 & 0.337 & 0.383 & 0.337 & 0.387 & 0.353 & 0.407 & 0.377 & 0.290 & 0.267 & 0.337 & 0.293 & 0.320 & 0.293 & 0.353 & 0.323 \\
\hline CD@ $5 \%$ & $\begin{array}{l}\text { A }(\mathrm{AN} \\
\text { B (Str } \\
\mathrm{A} \times \mathrm{B}\end{array}$ & $\begin{array}{l}\text { F treatn } \\
\text { ss treatr } \\
\text { interact }\end{array}$ & $\begin{array}{l}\text { (ent) }-0 \\
\text { lent })-( \\
\text { on })-0 \text {. }\end{array}$ & $\begin{array}{l}650 \\
.650 \\
919 \\
\end{array}$ & $\begin{array}{l}\text { A (AM } \\
\text { B (Stre } \\
\text { A x B }\end{array}$ & $\begin{array}{l}\text { F treatn } \\
\text { ss treatr } \\
\text { interact }\end{array}$ & $\begin{array}{l}\text { lent })-0 \\
\text { hent })-(\text { on })-N\end{array}$ & $\begin{array}{l}962 \\
.962 \\
\text { S. }\end{array}$ & $\begin{array}{l}\mathrm{A}(\mathrm{AM} \\
\mathrm{B} \text { (Stre } \\
\mathrm{A} \times \mathrm{B}\end{array}$ & $\begin{array}{l}\text { F treatm } \\
\text { ss treatn } \\
\text { interact }\end{array}$ & $\begin{array}{l}\text { ent) }-0 \\
\text { (ent) }-( \\
\text { on })-\mathrm{N}\end{array}$ & $\begin{array}{l}496 \\
496 \\
\text { S. } \\
\end{array}$ & $\begin{array}{l}\text { A (AN } \\
\text { B (Str } \\
\text { A x B }\end{array}$ & $\begin{array}{l}\text { F treatm } \\
\text { ss treatn } \\
\text { interact }\end{array}$ & $\begin{array}{l}\text { ent) }-0 \\
\text { ent) }-0 \\
\text { on) }-\mathrm{N}\end{array}$ & $\begin{array}{l}421 \\
.596 \\
\text { S. } \\
\end{array}$ \\
\hline
\end{tabular}


Table.4 Effect of Arbuscular mycorrhizal fungi on potassium content in wheat plants under control and drought stress condition at different growth stages

\begin{tabular}{|c|c|c|c|c|c|c|c|c|c|c|c|c|c|c|c|c|}
\hline Part of plant & \multicolumn{8}{|c|}{ Leaves } & \multicolumn{8}{|c|}{ Roots } \\
\hline Varieties & \multicolumn{4}{|c|}{ WH - 1025} & \multicolumn{4}{|c|}{ WH - 1105} & \multicolumn{4}{|c|}{ WH - 1025} & \multicolumn{4}{|c|}{ WH - 1105} \\
\hline Stage & \multicolumn{2}{|c|}{ Jointing } & \multicolumn{2}{|c|}{ Heading } & \multicolumn{2}{|c|}{ Jointing } & \multicolumn{2}{|c|}{ Heading } & \multicolumn{2}{|c|}{ Jointing } & \multicolumn{2}{|c|}{ Heading } & \multicolumn{2}{|c|}{ Jointing } & \multicolumn{2}{|c|}{ Heading } \\
\hline $\begin{array}{c}\text { Non AMF } \\
\text { (uninoculated) }\end{array}$ & 1.88 & 1.74 & 2.06 & 1.90 & 1.88 & 1.74 & 2.11 & 1.90 & 1.51 & 1.46 & $\begin{array}{c}1.63 \\
7\end{array}$ & $\begin{array}{c}1.55 \\
2\end{array}$ & 1.57 & 1.44 & $\begin{array}{c}1.67 \\
7\end{array}$ & $\begin{array}{c}1.56 \\
7\end{array}$ \\
\hline CD@ 5\% & $\begin{array}{l}\mathrm{A}(\mathrm{A}) \\
\mathrm{B}(\mathrm{St} \\
0.635 \\
\mathrm{~A} \times \mathrm{B}\end{array}$ & $\begin{array}{l}\text { F trea } \\
\text { ss tre }\end{array}$ & $\begin{array}{l}\text { nent) - } \\
\text { nent) } \\
\text { (ion) - }\end{array}$ & $\begin{array}{r}0.635 \\
.898\end{array}$ & $\begin{array}{l}\mathrm{A}(\mathrm{AN} \\
\mathrm{B}(\mathrm{Str} \\
\mathrm{A} \times \mathrm{B}\end{array}$ & $\begin{array}{l}\text { IF trea } \\
\text { ins trea }\end{array}$ & $\begin{array}{l}\text { nent) - } \\
\text { ment) - } \\
\text { (ion) - }\end{array}$ & $\begin{array}{r}0.898 \\
0.898 \\
.270\end{array}$ & $\begin{array}{l}\text { A (Al } \\
\text { B (Str } \\
\text { A x B }\end{array}$ & $\begin{array}{l}\text { F treat } \\
\text { ss trea } \\
\text { intera }\end{array}$ & $\begin{array}{l}\text { nent) - } \\
\text { nent) - } \\
\text { ion) - }\end{array}$ & $\begin{array}{l}1.831 \\
1.831 \\
.590\end{array}$ & $\begin{array}{l}\mathrm{A}(\mathrm{Al} \\
\mathrm{B}(\mathrm{St}) \\
\mathrm{A} \times \mathrm{B}\end{array}$ & $\begin{array}{l}\text { IF treat } \\
\text { ss trea } \\
\text { intera }\end{array}$ & $\begin{array}{l}\text { nent) - } \\
\text { nent) - } \\
\text { ion) - }\end{array}$ & $\begin{array}{r}.748 \\
0.748 \\
.058\end{array}$ \\
\hline
\end{tabular}


Fig.1 Effect of Arbuscular mycorrhizal fungi on nitrate reductase activity in wheat plants under control and drought stress condition at different growth stages

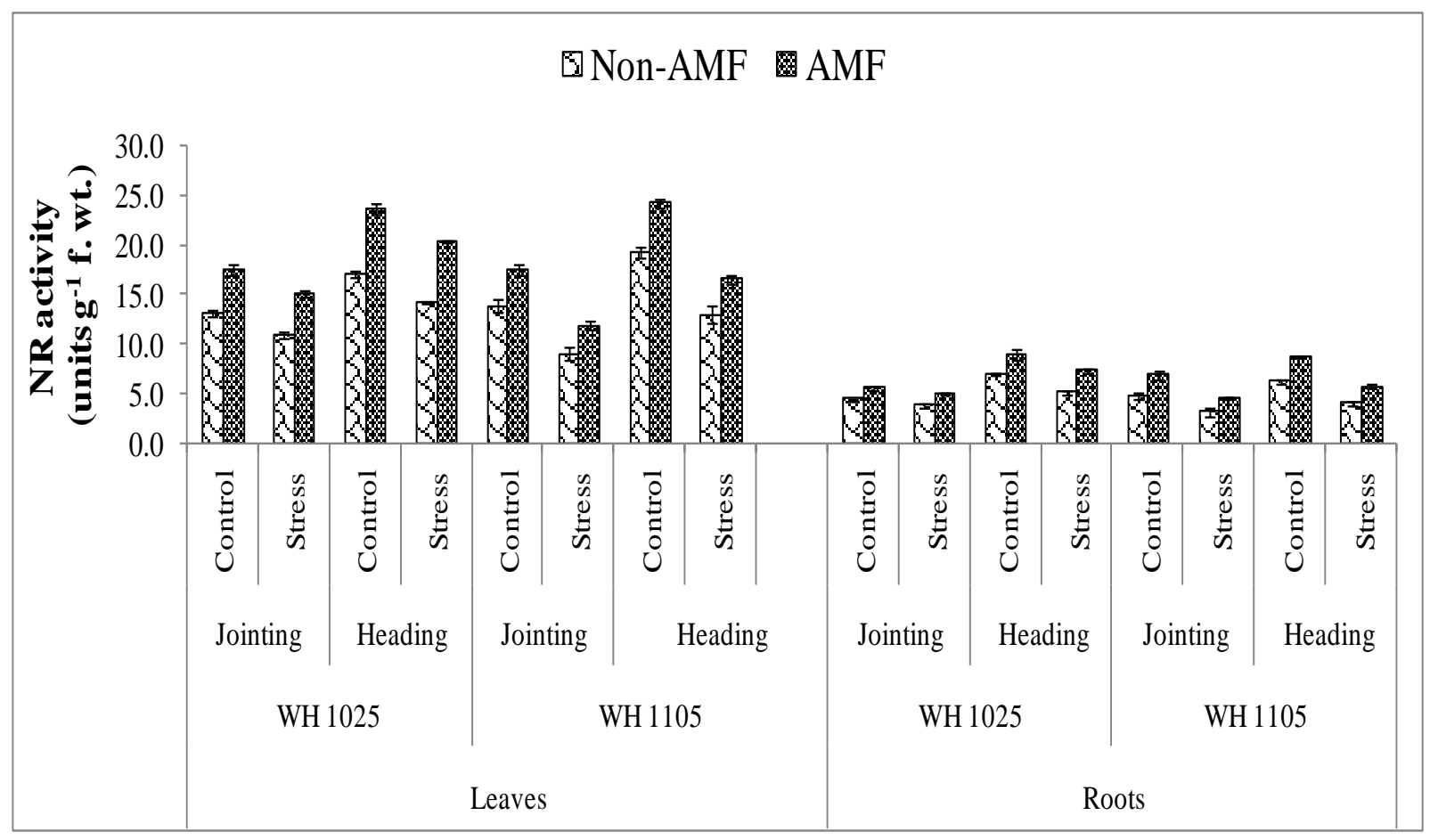

Fig.2 Effect of Arbuscular mycorrhizal fungi on nitrite reductase activity in wheat plants under control and drought stress condition at different growth stages

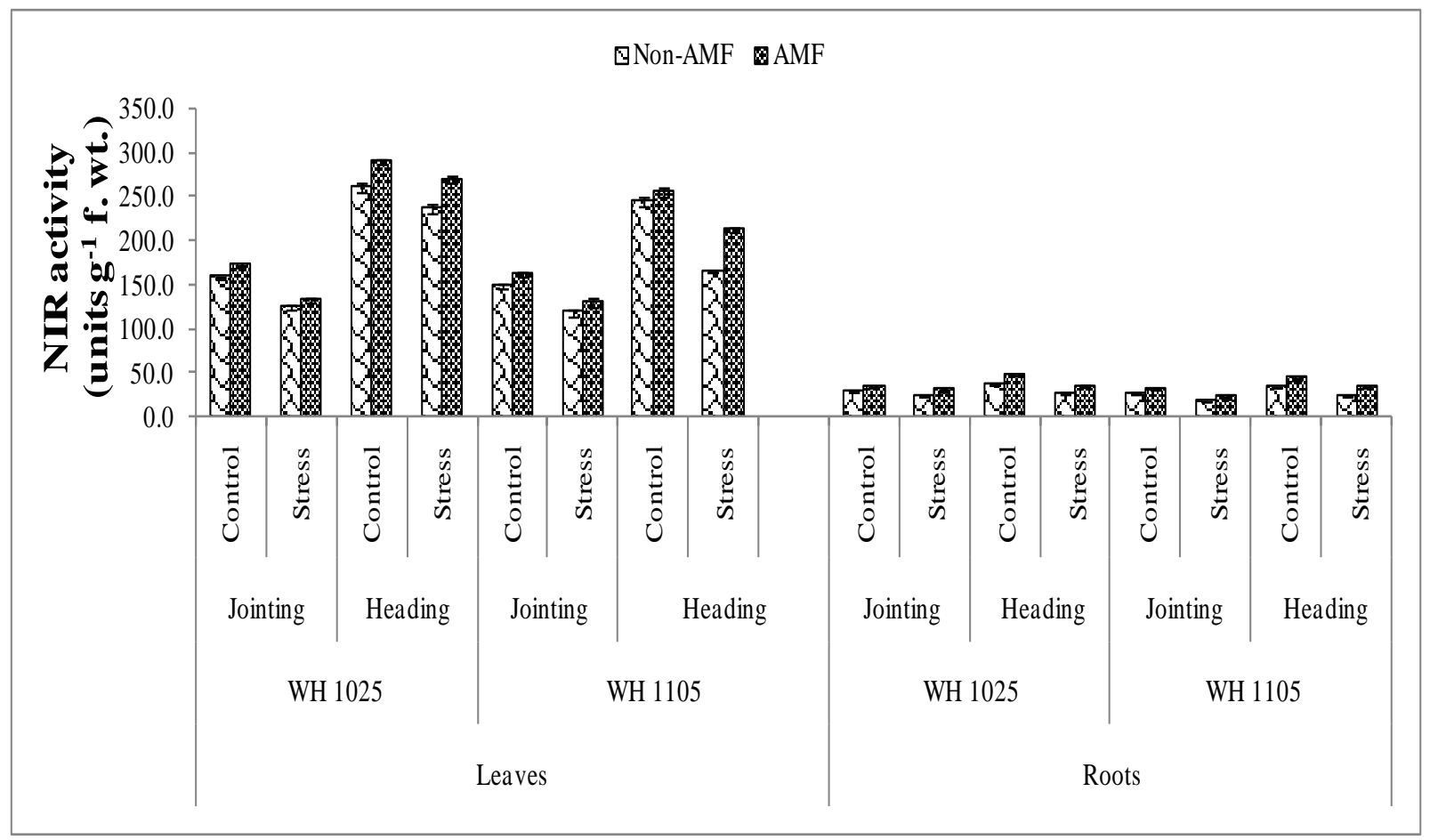


Fig.3 Effect of Arbuscular mycorrhizal fungi on glutamine synthetase activity in wheat plants under control and drought stress condition at different growth stages

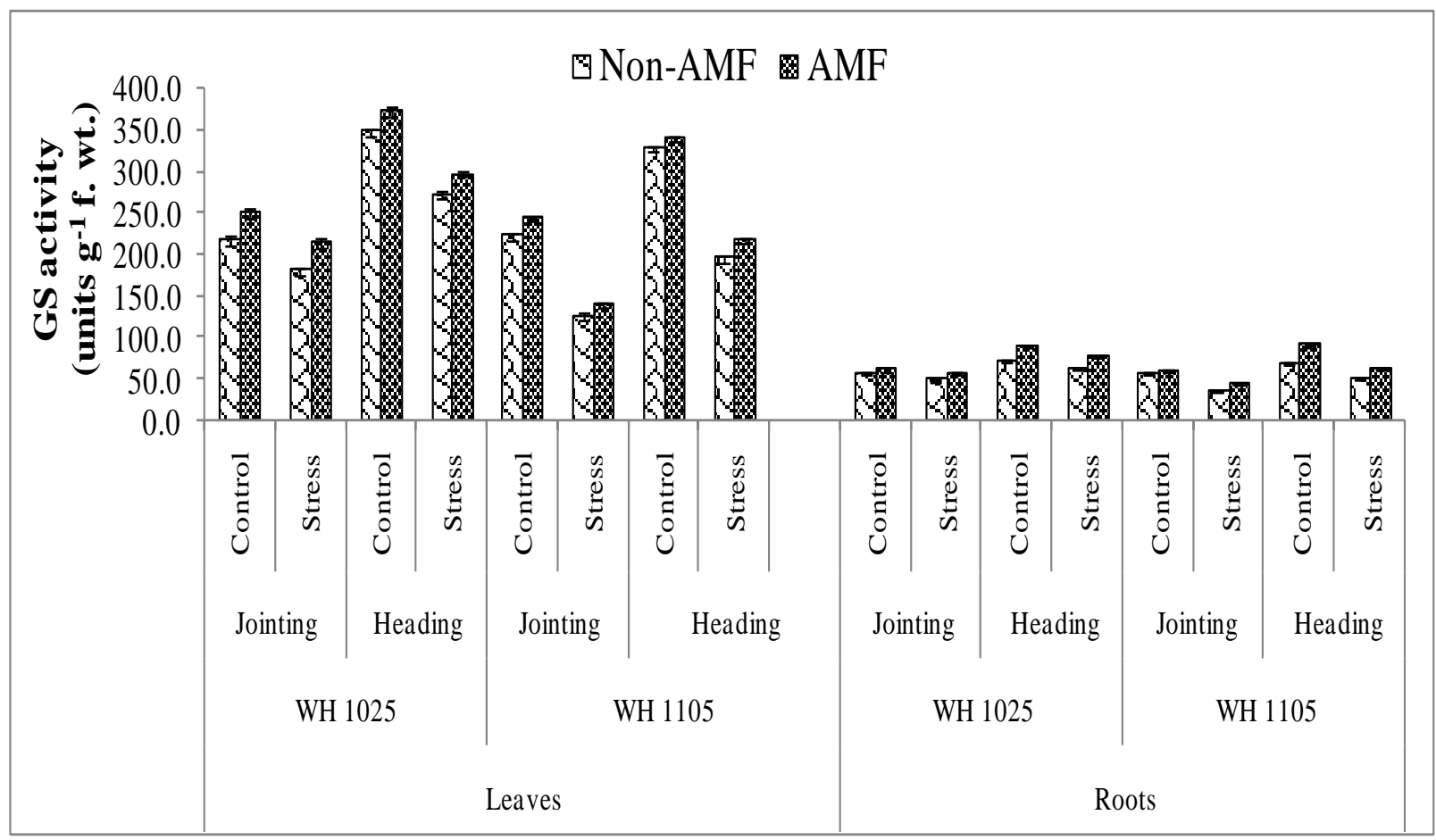

Fig.4 Effect of Arbuscular mycorrhizal fungi on acid phosphatase activity in wheat plants under control and drought stress condition at different growth stages

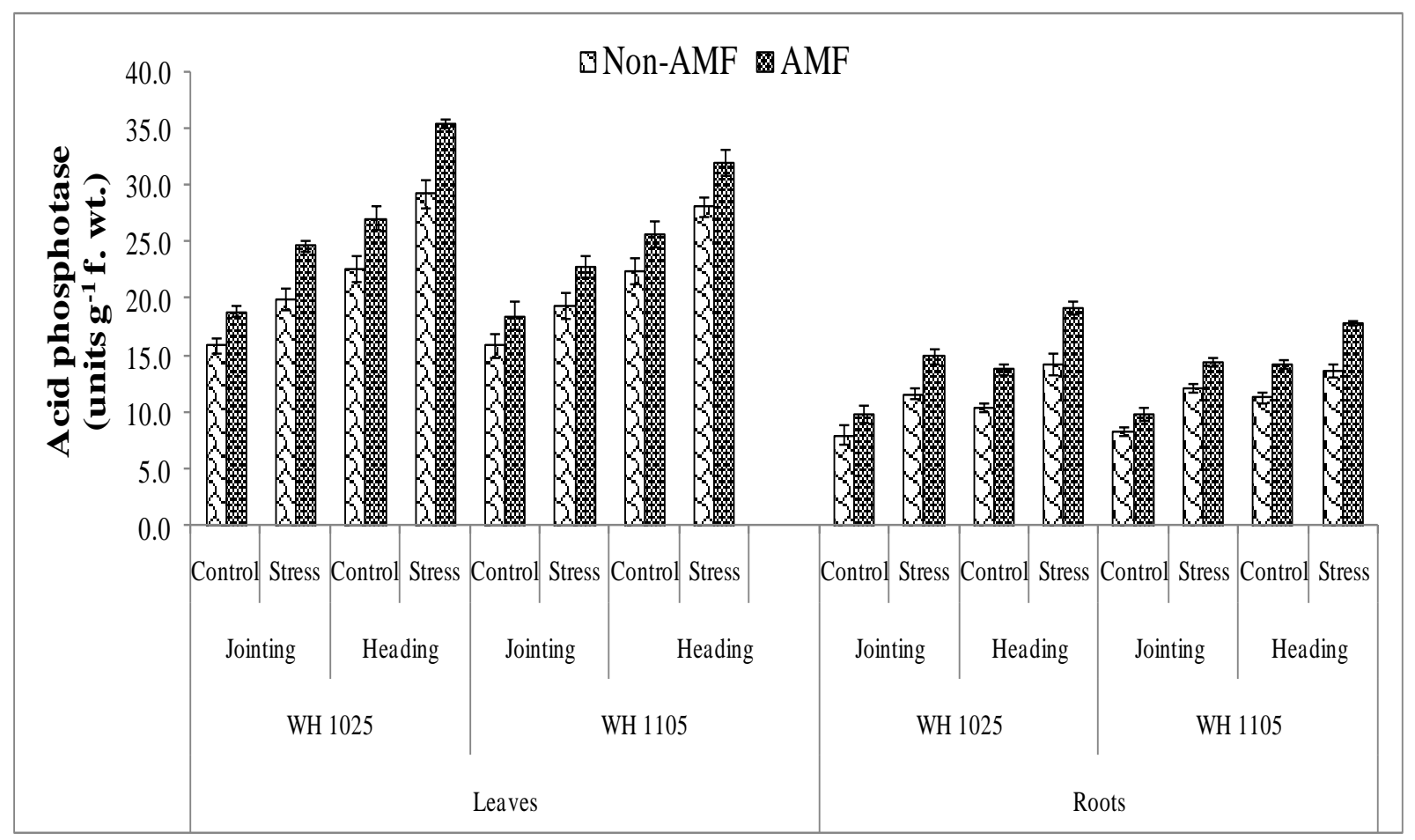


Fig.5 Effect of Arbuscular mycorrhizal fungi on alkaline phosphatase activity in wheat plants under control and drought stress condition at different growth stages

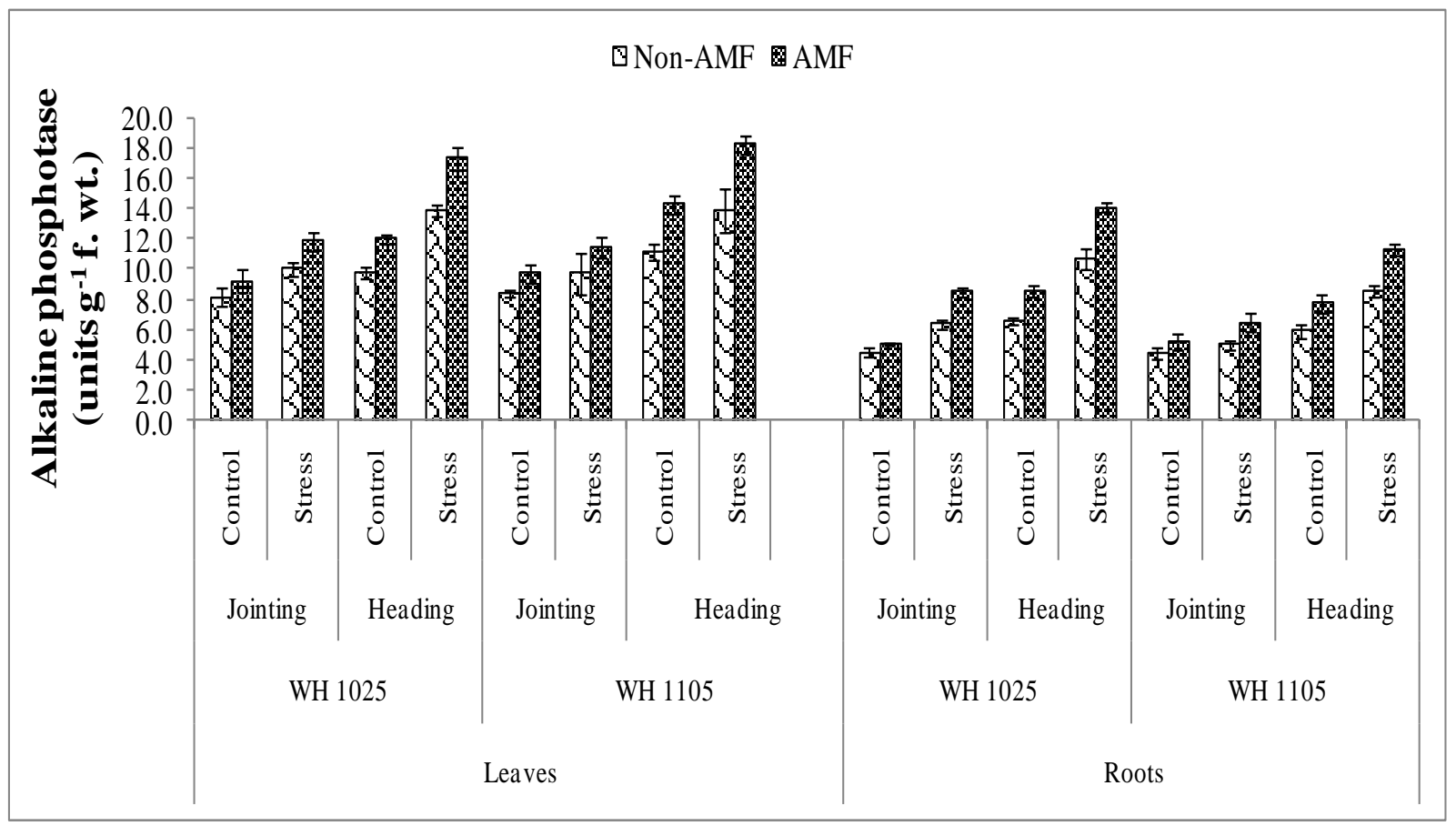

\section{Nitrogen, Phosphorous and potassium content of soil}

Nitrogen, phosphorous and potassium content in leaves and roots decreased under drought stress in AMF inoculated and uninoculated plants at jointing and heading stages of wheat varieties viz. WH 1025 and WH 1105. However, the per cent reduction was higher in uninoculated plants as compared to AMF inoculated plants (Table 2, 3 and 4).

Results presented in Table 1 show the N, P and $\mathrm{K}$ content in soil before sowing and after harvesting. It was observed that all three nutrients decreased in soil after harvesting as compared to before sowing. Nitrogen, phosphorous and potassium content decreased under drought stress, however with AMF inoculation increased in leaves and roots of both the varieties (Tables 2, 3 and 4). Under water stress conditions in AMF uninoculated and inoculated leaves of WH 1025, nitrogen content decreased by 4.9 and $5.8 \%$ at jointing and 6.1 and $6.7 \%$ at heading stage respectively (Table 2). In WH 1105 similar pattern was observed as in WH 1025, but basal level was found higher in WH 1105 as compared to WH 1025 irrespective of AMF treatments. In roots of WH 1105 AMF uninoculated and inoculated plants $\mathrm{N}$ content decreased by 5.7 and $4.0 \%$ at jointing and 7.0 and $4.8 \%$ at heading stage under stress conditions. In AMF inoculated leaves of WH 1025, N content under control and stressed conditions increased by 20.5 and $23.4 \%$ at jointing and 23.3 and $22.2 \%$ at heading stage respectively as compared to uninoculated plants (Table 2).

Phosphorous content in AMF inoculated plants of WH 1025 , increased by 8.8 and $11.8 \%$ but in WH 1105 increased by 11.4 and $7.9 \%$ at jointing and heading stage respectively under stress conditions (Table 3). The level of phosphorous was found higher in roots of WH 
1105 than in WH 1025 variety at jointing and heading stage under control conditions but more reduction was observed under stress conditions. Under stress conditions phosphorous content with AMF inoculation in WH 1025, increased by 33.3 and $35.4 \%$ however, in WH 1025 increased by 47.2 and $51.6 \%$, in $\mathrm{WH} 1105$ at jointing and heading stage (Table 3 ).

Potassium content in AMF inoculated leaves of WH 1025, potassium content increased by 6.5 and $2.8 \%$ and in WH 1105 increased by 5.0 and $8.9 \%$ at jointing and heading stage respectively under water stress conditions (Table 4). In WH 1105 similar pattern was observed as in WH 1025. In roots of WH 1105 AMF uninoculated and inoculated plants potassium content decreased by 9.0 and $6.5 \%$ at jointing and 7.0 and $5.5 \%$ at heading stage under water limiting conditions. In AMF inoculated roots of WH 1025, potassium content under control and stressed conditions increased by 3.6 and $2.8 \%$ at jointing and 2.7 and $4.1 \%$ at heading stage respectively as compared to uninoculated plants (Table 4).

Similar results were found in wheat plants that the concentration of elements $(\mathrm{N}, \mathrm{P}$ and $\mathrm{K})$ under water stress was reduced when compared to control plants by (Abo-Ghalia and Khalafallah, 2008; Al-Karaki et al., 2004). In present study, N, P and $K$ were significantly higher in leaves and roots of water stress mycorrhizal inoculated plants than those in uninoculated wheat plants. These findings are in concomitant with those of previous investigators who have reported that arbuscular mycorrhizal fungi absorb higher $\mathrm{N}$ and $\mathrm{P}$ than the control plants during drought stress (Miransari et al., 2008). Furthermore, the protection of the mycorrhizal plants against drought stress was related to the mycorrhizal induction of leaf conductance (Asrar and Elhindi, 2011) and transpiration (Auge, 2001) as well as P, N, and $\mathrm{K}$ uptake. Potassium plays a key role in plant water stress and its cationic nature is responsible for stomatal movement (Auge et al., 2007). One of the most common explanations for the improved nutrient status in mycorrhizal plants is the enhanced absorbing surface provided by the hyphae in the soil together with the ability of fungi to take up water from soil with low water potential (Ruiz-Lozano et al., 1995). AMF symbiosis is considered to be the most common strategy for enhancing $\mathrm{P}$ availability in the soil and $\mathrm{P}$ uptake capacity of the plants (Azcon et al., 2001).

Based upon the results obtained in better performance of AMF inoculated plants of WH 1025 under stress may be due to AMF symbiosis which might enhance activities of NR, NIR, GS, Acid and Alkaline phosphatase. Higher N, P and $\mathrm{K}$ content in AMF inoculated plants under water stress may contribute to the better stress tolerance of WH1025 as compared to WH1105.

\section{Disclosure statement}

No conflict of interest was reported by the authors.

\section{Acknowledgement}

The authors are thankful to the Head, Department of Biochemistry, for providing the required research facilities.

\section{References}

Abo-Ghalia, H.H., and Khalafallah, A, A. 2008. Responses of wheat plants associated with arbuscular mycorrhizal fungi to short-term water stress followed by recovery at three growth stages. J Appl Sci Res. 4:570-580.

Al-Karaki, G.N., McMichael, B. and Zah, J. 2004. Field response of wheat to 
arbuscular mycorrhizal fungi and drought stress. Mycorrhiza. 14:263-269.

Almagrabi, O.A., and Abdelmoneim, T.S. 2012. Using of arbuscular mycorrhizal fungi to reduce the deficiency effect of phosphorous fertilization on maize plants (Zea mays L.). Life Science Journal. 9:1648-1654.

AOAC. 2000. Official method of analysis $17^{\text {th }}$ Ed. Inc., Maryland, USA.

Auge, R.M., 2001. Water relations, drought and vesicular-arbuscular mycorrhizal symbiosis. Mycorrhiza. 11:3-42.

Auge, R.M., Toler, H.D., Moore, J.L., Cho, K. and Saxton, A.M. 2007. Comparing contributions of soil versus root colonization to variations in stomatal behavior and soil drying in mycorrhizal Sorghum bicolor and Cucurbita pepo. Journal of Plant Physiology. 164:12891299.

Azcon, R., Ruiz-Lozano, J.M. and Rodriguez, R. 2001. Differential contribution of arbuscular mycorrhizal fungi to plant nitrate uptake $(15 \mathrm{~N})$ under increasing $\mathrm{N}$ supply to the soil. Canadian Journal of Botany. 79:1175-1180

Boland, M., Fordyce, H. and Greenwood R. 1978. Enzymes of nitrogen metabolism in legume nodules: A comparative study. Functional Plant Biology. 5:553559.

Fewson, C.A., and Nicholas, A. 1961. Nitrate reductase from Pseudomonas aeruginosa. Biochemistry and Biophysiology Acta. 49:335-349.

Fresneau, C., Ghashghaie, J. and Cornic, G. 2007. Drought effect on nitrate reductase and sucrose-phosphate synthases activities in wheat (Triticum durum L.) role of leaf internal $\mathrm{CO}_{2}$. Journal of Experimental Botany. 58:2983-2992.

Gebauer, G., and Meyer M. 2003. ${ }^{15} \mathrm{~N}$ and ${ }^{13} \mathrm{C}$ natural abundance of autotrophic and myco-heterotrophic orchids provides insight into nitrogen and carbon gain from fungal association. New Phytology. 160(1):209-223

Guescini, M., Zeppa, S., Pierleoni, R., Sisti, D., Stocchi, L. and Stocchi, V. 2007. The expression profile of the Tuber borchii nitrite reductase suggests its positive contribution to host plant nitrogen nutrition. Current Genetics. 51:31-41.

Hajong, S., Kumaria, S. and Tandon, P. 2013. Comparative study of key phosphorus and nitrogen metabolizing enzymes in mycorrhizal and non-mycorrhizal plants of Dendrobium chrysanthum Wall.ex Lindl. Acta Physiology Plantarum. 35:2311-2322

Hoagland, D.R., Arnon DI. 1950. California Agriculture Circular. California Agriculture Experimental Statistics. 347.

Ireland, R.J., and Lea, P.J. 1999. The enzymes of glutamine, glutamate, asparagine and aspartate metabolism. In: Singh, B.K. (Ed.), Plant Amino Acids: Biochemistry and Biotechnology. Marcel Dekker, New York, pp. 49-109.

Jackson, M.L., 1973. Soil chemical analysis. Prentice Hall of Indian Pvt. Ltd., New Delhi.

Jones, D.L., 1998. Organic acid in the rhizosphere - a critical review. Plant Soil. 205:25-44.

Kanamori, T. and Matsumoto, H. 1972. Glutamine Synthetase from rice plant roots. Arch Biochem and Biophy. 152:404-412.

Koenig, R.A., and Johnson, C.R. 1942. Colorimetric determination of $\mathrm{P}$ in biological materials. Industrial and Engineering Chemistry, Analytical Edition.. 14:155-56.

Miransari, M., Bahrami, H.A., Rejali, F. and Malakout, M.J. 2008. Using arbuscular mycorrhizae to alleviate the stress of soil compaction on wheat (Triticum 
aestivum L.) growth. Soil Biology and Biochemistry. 40:1197-1206.

Nisha, M.C., Kumar SR. 2010. Influence of arbuscular mycorrhizal fungi on biochemical changes in Wedilla chinensis (Osbeck) Merril. Ancient Sci life. 29:26-29.

Ratti, N., Verma, H.N. and Gautam, S.P. 2010. Effect of Glomus species on physiology and biochemistry of Catharanthus roseus. Indian Journal of Microbiology. 50:355-360.

Roldan, A., Diaz-Vivancos, P., Hernandez, J.A., Carrasco, L. and Caravaco, F. 2008. Superoxide dismutase and total peroxidase activities in relation to drought recovery performance of mycorrhizal shrub seedlings grown in an amended semiarid soil. Journal of Plant Physiology. 165:715-722.

Ruiz-Lozano, J.M., and Aroca, R. 2010. Modulation of aquaporin genes by the arbuscular mycorrhizal symbiosis in relation to osmotic stress tolerance. In: Seckbach J, Grube M (eds) Symbiosis and stress: joint ventures in biology, cellular origin, life in extreme habitats and astrobiology. Springer Science, Business Media, Dordrecht, pp 359-374

Ruiz-Lozano, J.M., Azcon, R. and Gomez, M. 1995. Effects of arbuscular mycorrhizal Glomus species on drought tolerance: physiological and nutritional plant responses. Applied Environmental Microbiology. 61:456-460.

Ruiz-Lozano, JM., 2003. Arbuscular mycorrhizal symbiosis and alleviation of osmotic stress.New perspectives for molecular studies. Mycorrhiza. 13:309317.

Sawhney, S.K., and Naik, M.S. 1972. Role of light in synthesis of nitrate reductase and nitrite reductase in rice seedling. Biochemical Journal. 130:475-485.

Semenov, M.A., and Shewry, P.R. 2011. Modelling predicts that heat stress and not drought will limit wheat yield in Europe. Scientific Reports. 1:1-5.

Sibout, R., and Guerrier, G. 1998. Solute incompatibility with glutamine synthetase in water-stressed Populus nigra. Environmental Experimental Botany. 40:173-178.

Smith, S.E., and Read, D.J. 2008. Mycorrhizal Symbiosis. $3^{\text {rd }} \quad$ ed. Academic Press, London.

Stancheva, I., Geneva, M., Djonova, E., Kaloyanova, N., Sichanova, M., Boychinova, M. and Georgiev, G. 2008. Response of alfalfa (Medicago sativa L.) growth at low accessible phosphorus source to the dual inoculation with mycorrhizal fungi and nitrogen fixing bacteria. General and Applied Plant Physiology. 34:319-326.

Tobar, R.M., Azcon, R. and Barea, J.M. 1994. Improved nitrogen uptake and transport from $15 \mathrm{~N}$-labelled nitrate by external hyphae of arbuscular mycorrhizae under water-stressed conditions. New Phytology. 126:119-122.

\section{How to cite this article:}

Babita Rani, Shashi Madan, K.D. Sharma, Pooja, Mukesh Kumar Berwal and Ashwani Kumar. 2017. Effect of Mycorrhizal Colonization on Nitrogen and Phosphorous Metabolism in Wheat (Triticum aestivum L.) under Water Deficit Stress. Int.J.Curr.Microbiol.App.Sci. 6(10): 916929. doi: https://doi.org/10.20546/ijcmas.2017.610.110 